\title{
NILAI BUDAYA DALAM PERIBAHASA KEI TENTANG PENGELOLAAN WILAYAH PESISIR
}

\author{
Wilma Akihary
}

\begin{tabular}{c} 
Email: wilamq@yahoo.com \\
Jurusan Bahasa dan Seni FKIP Universitas Pattimura Ambon \\
Alamat Koresponden: Jalan Ir. Putuhena Kampus Poka Ambon 97233 \\
\hline
\end{tabular}

\begin{abstract}
The cultural values that are covered in the way of life is manifested in men's activities. The cultural values themselves are symbolized through the proverbs. As the expression, the proverb is basically the principle guideline of behavior. Within the proverb is contained a profound experience of the world view as well as the life wisdom that is tightly integrated to the society to which the language belongs. The proverb - known as misil-masal, liat daliat and sukat sarang - is still well recorded and used by Kei community as Kei language speaker. The people who live in the coastal area especially at the Kei Besar Island are generally the fishermen and farmers. However, in this research it will focus on the Kei Besar people's view in managing their coastal area through the proverbs they use. The uses of words as the expression is closely related to the sea and their way of life especially in connected with fish and boat. The proverbs which are used by the people in Kei is the summary of their way of thinking about the values of life. The cultural values in these proverbs are firmness, strength, simplicity, mutual assistance, respect for the elders and leaders, wisdom, thinking before doing, and obedience.
\end{abstract}

\section{Keywords}

Nilai Budaya, Peribahasa, Wilayah Pesisir

\section{Pendahuluan}

Bahasa merupakan medium penting dalam semua interaksi manusia. Ia mengungkapkan pengalaman baik itu secara individu mapun secara kolektif (medium kollektiver Gefühlerlebnisses) dalam memandang dunia sekitarnya. Kesamaan cara pandang suatu masyarakat terhadap dunia di sekitarnya diekspresikan penutur bahasa tertentu sesuai dengan kesepakatan mereka. Kesepakatan ekspresi cara pandang masyarakat ini dikenal dengan istilah budaya. Budaya merupakan sesuatu yang diwariskan dari satu generasi ke generasi lain melalui tindakan manusia dan komunikasi linguistik (Duranti, 1997; McQuown dalam Dill, 1982).

Sebagai transmisi kebudayaan, bahasa digunakan untuk menyampaikan rekaman unsur dan nilainilai kebudayaan. Rekaman unsur dan nilai budaya ini merupakan kesepakatan penutur bahasa. Misalnya warna yang menurut penutur bahasa Berinho hanya terdiri atas lima warna pokok, yaitu hitam, putih, merah, kuning-orange-coklat, dan hijau-biru-ungu, sedangkan penutur bahasa Hunanco di Filipina hanya mengenal empat warna, yakni mabiru 'hitam dan warna gelap lain', melangit 'putih dan warna cerah', meramar 'kelompok warna merah, dan malatuy 'kuning, hijau muda dan coklat muda'. Kesepakatan untuk membagi spektrum warna ini bukan berarti menunjukan adanya perbedaan dalam kemampuan melihat warna. Melainkan merupakan perbedaan cara warna itu digolongkan atau disusun oleh dua penutur bahasa tersebut. Dengan kata lain, sistem kategorisasi diberikan oleh penutur berdasarkan kesepakatan menurut apa yang diterima melalui indranya dan diproses dalam pikiran serta membaginya dalam kelompok-kelompok. Pengindentifikasian, pengklasifikasi alam, dan pemberian nama/nomenklatur didasarkan atas persepsi dan pikiran mereka serta diungkapkan dan dipertahankan dalam bahasa mereka. Disini ditemukan semacam keteraturan dalam persepsi tentang lingkungannya. Dengan menganalisis pengkategorian atau pengklasifikasian lingkungan tersebut tidak hanya dapat diketahui bagaimana pandangan mereka tentang lingkungan baik alam maupun yang sosial, tetapi juga memahami logika yang membawahinya dan memahami aspek-aspek pengalaman apa yang dianggap penting (Kay dalam Jourdan dan Tuie, 2006; Masinambouw, 2004; Duranti, 1997; Chaer dan Agustina, 1995). 


\section{Penutup}

Sebagai alat untuk mencerminkan kekayaan budaya, peribahasa pun menyimpan sejumlah kearifan lokal. Ungkapan-ungkapan seperti yang terlihat dalam peribahasa membimbing perilaku masyarakat yang selaras dengan amanat leluhur dan memungkinan apresiasi dan pemahaman makna dan gagasan budaya yang telah terbina sejak dahulu.

Dari keseluruhan ungkapan yang muncul dalam peribahasa Kei, gambaran perilaku individu dan cara hidup dalam masyarakat sering dilukiskan melalui analogi tentang lingkungan sekitarnya. Penggunaan ungkapan-ungkapan itu bertujuan untuk menyindir, menasehati, menegaskan dan memperingatkan. Dari ungkapan tersebut tersirat pola pikir masyarakat Kei yang dalam ungkapan tersebut mengandung nilai kehidupan berupa ketegasan, ketegaran, kesederhanaan, kegotongroyongan, penghormatan terhadap orang yang lebih tua, berlaku bijaksana, berpikir sebelum bertindak dan kepatuhan.

Pengalaman masyarakat dalam mengelola dan memanfaatkan sumber daya alam di Kei bertumpu pada pandangan hidup mereka. Berdasarkan pemahaman mereka terhadap sistem pengetahuan tradisional yang telah diwariskan oleh para leluhur, mereka mampu menghadapai tantangan alam untuk memenuhi kebutuhan hidup mereka dan mempertahankannya dari satu generasi ke generasi lain.

\section{DAFTAR PUSTAKA}

Blust, R.A. 1977. The Proto Austronesian Pronoun and Austronesian Subgrouping Hypothesis, A Preliminary Report Working Paper in Linguistic.

Duranti, Alessandro. 1997. Linguistic Anthropololgy. Cambridge University Press

Chaer, Abdul dan Agustina, Leonni. 1995. Linguistik Suatu Pengantar. Jakarta: Rineka Cipta

Kay, Paul. 2006. Language, Culture and Society: Key Topic in Linguistic Anthropology. Jourdan, Christine dan Tuie, Kevin (Eds.). Cambridge: Cambridge University Press

Kridalaksana. 2008. Kamus Linguistik. Jakarta: Gramedia Pustaka Utama

Masinambow, E.K.M. 2004. Teori Kebudayaan dan Ilmu Pengetahuan Budaya. Dalam Christomy, T dan Untung Yuwono (Ed.), Semiotika Budaya. Jakarta: Pusat Penelitian Kemasyarakatan dan Budaya. Direktoral Riset dan Pengabdian Masyarakat. Universitas Indonesia

McQuown, N.A. 1982. Language, Culture and Education (A.S. Dill, Ed). Stanford: Stanford University Press.

Rahail, J.P. 1993. Larwul Ngabal. Jakarta: Sejati

Renyaan. 1989. Misil Masal, Liat Dalil, Sukat Sarang Evav. Langgur: Seminari Yudas Thadeus.

Travis, Ed. 1990. Bahasa Kei (Evav): Hasil Penelitian selama Satu Abad. (Online), (http://www.eli.org/main/pdf/pdf_417.pdf-), diakses 4 Juni 2011. 